JORDAN LIPSKI

\title{
SAFE HARBOUR: SHOULD WE BE WORRIED? \\ An Analysis of Clause 20 of the Harmful Digital \\ Communications Bill, and its Application to the \\ Law of Defamation
}

Submitted for the LLB (Honours) Degree

Faculty of Law

Victoria University of Wellington

2014 


\section{Abstract}

Liability of internet intermediaries for content created by third parties is a contentious area of defamation law. Recently, the law in New Zealand has begun to depart from English law, and move closer to strict liability. Parliament has responded with a 'safe harbour' in clause 20 of the Harmful Digital Communications Bill, which will provide online content hosts with conditional immunity from liability for content created by others. The author supports the creation of a legislative safe harbour for internet intermediaries, but highlights a number of deficiencies with clause 20 as currently drafted. This paper analyses the existing law, including possible defences, and clause 20. It also looks to other jurisdictions' safe harbours, and concludes with recommendations on how clause 20 ought to be improved.

\section{Keywords}

Defamation, Internet, Safe Harbour 


\section{Contents}

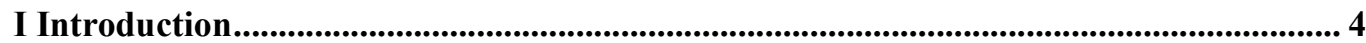

A Issues and structure of this paper ........................................................................ 4

B Background to defamation law......................................................................................... 5

II The Proposal for Reform ................................................................................................................ 5

A The original notice and takedown regime .................................................................... 6

B The notice and takedown regime now.............................................................................. 7

III The Current Position .................................................................................................. 9

A General law as to publishers............................................................................

B Whether internet intermediaries can be publishers of third party content .... 10

1 Liability of online content hosts ................................................................. 10

(a) England and Wales ................................................................. 10

(b) New Zealand ...................................................................................... 12

2 Liability of online search engine operators .................................................. 14

(a) England and Wales...................................................................... 14

(b) New Zealand ...................................................................................... 15

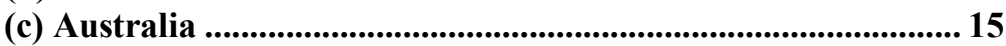

$C$ Whether the defence of innocent dissemination is available to internet intermediaries in respect of content posted by third parties ..................................... 16

D Conclusion on the current law............................................................................................. 18

IV Comparison with Similar Regimes Overseas .......................................................18

A United Kingdom..................................................................................................... 18

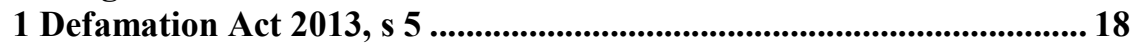

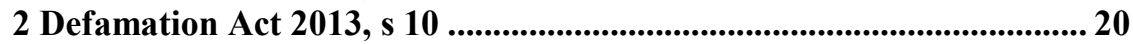

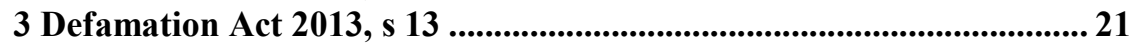

4 Summary .................................................................................................................. 21

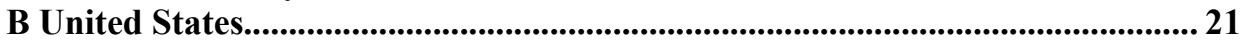

1 Communications Decency Act 1996, s 230 .............................................. 21

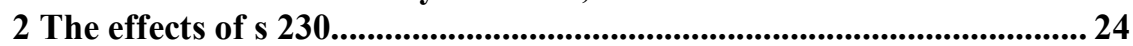

V Improvements to the Harmful Digital Communications Bill .......................................... 24

A Why a safe harbour is needed .................................................................................. 24

B Application to search engine operators ....................................................................... 26

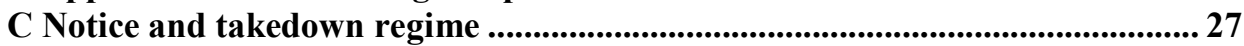

VI Conclusion .............................................................................................................................................. 29

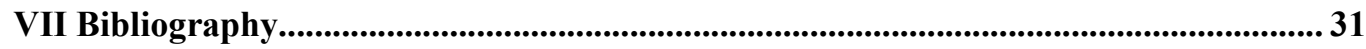




\section{Introduction}

The Harmful Digital Communications Bill, currently before Parliament, reforms the liability of online content hosts for defamatory content created by third parties: it provides what is commonly called a 'safe harbour', giving hosts immunity from civil and criminal actions in respect of content created by others. The provision has potentially far-reaching effects, and particularly so in the field of defamation, which is therefore this paper's focus in analysing the provision.

\section{A Issues and structure of this paper}

After introducing the law of defamation, this paper will discuss the Bill's safe harbour regime. This will involve looking at what it is in its current form, and what it was before changes were made following the Select Committee's recommendations. The clause, as initially drafted, had significant deficiencies that could restrict freedom of expression by incentivising the quick removal of content complained of. The Select Committee made several recommendations, which were adopted by the Minister, but there are still a number of issues with the provision.

The paper will then look to the prior law on online content hosts' liability for third party defamation to see how the Bill fits in and what it will change. Case law has been confused, particularly with respect to the separate questions of whether a defendant is a publisher for the purposes of defamation liability, and whether the defendant can avail itself of the defence of innocent dissemination. Notably, recent New Zealand cases have begun to move away from the English law, towards stricter liability in respect of third party defamation.

The paper also argues that the Bill's safe harbour may not apply to search engines, and that Parliament should clarify that search engines are covered.

Finally, the paper will consider the importance of giving internet intermediaries immunity, and will look to foreign jurisdictions and make recommendations on how the Bill should be improved. It will particularly focus on the United Kingdom's Defamation Act 2013 and the United States' Communications Decency Act 1996. 
People are generally entitled to their reputation, and have a right to claim that their reputation should not be disparaged by defamatory statements made about them without lawful justification or excuse. ${ }^{1}$ Defamation is a private legal remedy, the objects of which are to vindicate the plaintiff's reputation and provide compensation for injury to reputation. ${ }^{2}$ The application of the law of defamation to situations in which the defamatory material was authored not by the defendant but by a third party has been contentious, especially so in the context of internet intermediaries.

\section{The Proposal for Reform}

The Harmful Digital Communications Bill ${ }^{3}$ (the Bill) was introduced by Hon Judith Collins on 5 November 2013. It contains a number of amendments to the law, and notably cl 20 provides what is commonly called a 'safe harbour' for online content hosts, supplemented by cl 20A. This safe harbour is conditional, but will apply very broadly, to any civil or criminal proceedings, ${ }^{4}$ with only a few specified exceptions. Clause 20(2) provides that:

"No civil or criminal proceedings may be brought against the online content host in respect of the content complained of (the specific content)".

"Online content host" is defined in the Act as the person who has control over the part of the electronic retrieval system, such as a website or online application, on which the communication is posted and accessible by the user. ${ }^{5}$ Thus the basis of application is control over the relevant part of the site or application, so it is clear that the provision will apply to operators of websites, blogs, Facebook pages and similar platforms.

This paper's analysis is limited to the clauses' application to defamation law, but it is important to note that the provision will apply to similar causes of action such as

\footnotetext{
${ }^{1}$ Laws of New Zealand Defamation at [1].

${ }^{2}$ At [1].

${ }^{3}$ Harmful Digital Communications Bill 2013 (168-2) [HDCB].

${ }^{4}$ Clause 20(2).

5 Clause 4.
} 
breach of confidence and the invasion of privacy tort from the Hosking $v$ Runting line of cases, as well as negligence; it will also presumably apply beyond common law torts, for example to liability under the Fair Trading Act $1986 .{ }^{6}$ Such consequences are beyond the scope of this article.

The paper's focus is on defamation for two main reasons: first, defamation is the cause of action likely to be most affected, in that the tort has increasingly been used in respect of content created by third parties and posted online; and secondly, it is clear from the Bill's legislative history that $\mathrm{cl} 20$ is primarily a response to two recent court decisions on defamation, which are discussed in part III below: Karam v Parker, and Wishart v Murray. ${ }^{7}$

\section{A The original notice and takedown regime}

Initially the safe harbour took a form that could be called a simple 'notice-takedown' model. In essence, an online content host would receive protection from civil and criminal liability provided it takes reasonable steps as soon as is reasonably practicable to remove content complained of.

The principal problem with this approach is that it incentivises the hasty removal of complained-of content by hosts, leading to restrictions on free speech. The notice of complaint was required to explain why the complainant considers that the specific content is unlawful, or otherwise ought to be taken down because it is harmful or objectionable. However, no required standard was specified, and there was no provision for the host to receive immunity should it weigh up the complaint and decide to leave the content in place - it could only attain immunity under the Act by taking reasonable steps to remove content about which it has received a complaint. Similarly, there was no way for an author of the content to challenge the complaint.

Consequently, content hosts would be likely to remove content in order to attain protection under $\mathrm{cl} 20$, regardless of whether the complaint is well grounded.

\footnotetext{
${ }^{6}$ Auckland District Law Society Inc "Submission to the Justice and Electoral Committee on the Harmful Digital Communications Bill 2013" at [21].

7 (14 November 2013) 694 NZPD 14747.
} 
Although no s 7 report has been issued by the Attorney-General, the Ministry of Justice considered the original clause to comply with the Bill of Rights Act 1990, for three reasons. ${ }^{8}$ First, the decision of a private provider of communications services to accept or delete communications has been held to fall beyond the Bill of Rights Act. Secondly, there is already an incentive for content hosts to refrain from hosting or retaining potentially offensive communications, given the risk of liability. Thirdly, there is Court of Appeal authority that a statutory immunity from liability does not engage Bill of Rights obligations because it does not constitute performance of a public function, power or duty conferred or imposed on that person or body by or pursuant to law. Unfortunately, no further explanation or citation was given.

\section{$B \quad$ The notice and takedown regime now}

Several changes were made to the procedure that online content hosts must follow in order to be protected by safe harbour, following recommendations by the Justice and Electoral Committee. In essence, the provision now requires that the host, as soon as possible but in any event within 48 hours of receiving a complaint, ${ }^{9}$ must provide the author of the content with a copy of the notice of complaint, ${ }^{10}$ and notify the author that the author may submit a counter-notice to the host within 48 hours after receiving that notification. ${ }^{11}$

From there, the action the host must take will vary, depending on which eventuality occurs. First, if the host is unable to contact the author after taking reasonable steps to do so, the host must take down or disable the specific content as soon as practicable. ${ }^{12}$

Secondly, if the author submits a valid counter-notice within 48 hours after receiving the host's notification, in which the author consents to the removal of the specific content, the host must take down or disable the specific content as soon as practicable. $^{13}$

\footnotetext{
${ }^{8}$ Ben Keith and Helen Carrad Harmful Digital Communications Bill (PCO 16465/4.17): Consistency with the New Zealand Bill of Rights Act 1990 (Ministry of Justice Advice to the Attorney-General, 2013). 
Thirdly, if the author submits a valid counter-notice in which the author refuses to consent to the removal of the specific content, the host must leave the specific content in place and, as soon as practicable, ${ }^{14}$ notify the complainant of the author's decision. ${ }^{15}$ If the author consents, the host must also provide the complainant with personal information that identifies the author. ${ }^{16}$

Lastly, if the author does not submit a valid counter-notice in accordance with the provisions, the host must take down or disable the specific content as soon as practicable but no later than 48 hours after notifying the author. ${ }^{17}$

In any event, the host must provide an easily accessible mechanism that enables a user to contact the host about content. ${ }^{18}$

The changes stem from a Ministry of Justice Departmental Report, which highlights the potential for the original $\mathrm{cl} 20$ to be misused, and the incentive for hosts to remove content complained about. ${ }^{19}$ The Ministry said that no alternative models considered were entirely suitable, ${ }^{20}$ and that the model eventually adopted strikes a balance between the timely removal of harmful content, the rights of authors of content and the freedom of expression, and the need for a model that is technically workable. ${ }^{21}$

Legislative reform should be consistent with the Bill of Rights Act 1990, so any restriction on freedom of expression should only be "such reasonable limits ... as can be demonstrably justified in a free and democratic society". ${ }^{22}$ As mentioned already, the Ministry of Justice considered the original cl 20 to be consistent with the Act. As now drafted, the clause is arguably even more consistent with s 14, because it does not give online content hosts an incentive to hastily remove content, thus lessening interference with freedom of expression.

\footnotetext{
${ }^{14}$ HDCB, above n 3, cl 20(3)(d).

${ }^{15}$ Clause $20(3)(d)(i)$.

${ }^{16}$ Clause $20(3)(d)(i i)$.

17 Clause $20(3)(\mathrm{e})$.

18 Clause 20(6).

${ }^{19}$ Ministry of Justice Harmful Digital Communications Bill - Departmental Report for the Justice and Electoral Committee (13 April 2014) at [287].

20 At [306].

21 At [314].

22 Bill of Rights Act 1990, s 5.
} 
However, the Bill contains a number of deficiencies. The first is that search engine operators may not be covered by $\mathrm{cl} 20$, under the provision's current wording. The second is that complainants may be left without a timely remedy, because the author can choose not to let the host pass on the author's details to the complainant. There are additional changes that should be made, to improve the safe harbour. These are discussed under part $\mathrm{V}$ below.

In order to provide context, I now turn to the law of defamation for third party content as it currently stands.

\section{Current Position}

There are two key issues in the question of whether an online content host can be liable for defamatory material created by a third party: first, whether the host is a "publisher" of the material for the purposes of defamation; and secondly, whether the host can avail itself of a defence, most relevantly the defence of innocent dissemination, which in New Zealand is codified in s 21 of the Defamation Act 1992. While these are distinct issues, the common law is somewhat murky because judges have not always clearly distinguished between them. This stems from the foundational case of Byrne, below, which departed from the tort's strict liability nature in respect of third party defamation.

\section{A General law as to publishers}

What constitutes publication is very broad: the communication of a defamatory statement to any person besides the subject of the statement. ${ }^{23}$ The traditional common law doctrine is that liability extends to anyone who participated in, secured or authorised the publication, ${ }^{24}$ subject to the defence of innocent dissemination.

Defamation is a strict liability tort, and Patteson $\mathrm{J}$ in Day $v$ Bream said that a defendant is prima facie liable even if he had no knowledge of the contents of the publication. ${ }^{25}$

\footnotetext{
${ }^{23}$ Pullman $v$ Walter Hill \& Co Ltd [1891] 1 QB 524 (QB) at 527.

${ }^{24}$ Mahfouz v Brisard [2005] EWHC 2304 (QB) at [11].

${ }^{25}$ Day v Bream (1837) 174 ER 212 (Assizes) at [56].
} 
The leading authority ${ }^{26}$ on liability for third party defamation is the English case of Byrne v Deane (Byrne). ${ }^{27}$ In that case, the Court held that the defendants, having control over their noticeboard, were publishers of defamatory material posted on it by a third party. The Court reasoned that by knowing of the defamatory material, having the power to remove it and failing to do so, they can properly be inferred to have taken responsibility for its continued publication. ${ }^{28}$ This departs from the normally strict liability nature of the tort.

It is worth noting that, in the context of online material, publication itself occurs where and when the offending statement is downloaded and read. ${ }^{29}$

As discussed below, case law reveals diverging views on whether knowledge of the defamatory material is necessary, as in the Byrne case, or whether it is not necessary, in line with the strict liability nature of the tort. As noted, this may stem from a failure to understand the distinction between being a publisher (which is defined broadly enough that even librarians have been held to be) and being an innocent disseminator, which carries a defence.

I will look separately at liability of online content hosts, and liability of search engines.

\section{$1 \quad$ Liability of online content hosts}

\section{(a) England and Wales}

Godfrey v Demon Internet Ltd (Demon) $)^{30}$ is, on its facts, an application of the Byrne approach to an online bulletin board operator. The Court held that the defendant, a Usenet bulletin board provider, was not just a conduit, because it hosted and transmitted the offending material and could delete it if it wished; ${ }^{31}$ thus it published

\footnotetext{
${ }^{26}$ Matthew Collins The Law of Defamation and the Internet (3rd ed, Oxford University Press, New York, 2011) at [6.22].

${ }^{27}$ Byrne v Deane [1937] 1 KB 818 [Byrne].

${ }^{28}$ At 838.

${ }^{29}$ Solicitor-General v Siemer HC Auckland CIV 2008-202, 8 July 2008 at [70].

${ }^{30}$ Godfrey v Demon Internet Ltd [2001] QB 201, [1999] 4 ER 342 (QB) [Godfrey].

${ }^{31}$ At 209.
} 
users' postings when it transmitted the information to viewers. ${ }^{32}$ Morland $\mathrm{J}$ considered the defendant to be analogous to a bookseller and library. ${ }^{33}$ Interestingly, he considered that the defendant could be liable even if it was not aware of the defamatory material, on the basis that liability for the publication of defamatory material was strict at common law, and there was still publication even if the publisher was ignorant of the defamatory material within the document. ${ }^{34}$ This obiter dictum departs from the reasoning in Byrne, and is more consistent with the foundations of the tort.

Tamiz v Google Inc (Tamiz) ${ }^{35}$ took a different approach, more closely following and endorsing the Byrne line of authority. ${ }^{36}$ The Court considered that Google, in respect of its Blogger.com service, was analogous to a noticeboard provider, in that it gave creators tools to make their posts. Google could set the terms of use, and readily block access for violation of such terms. Thus it would be a publisher once it had received notification. ${ }^{37}$ The Court doubted that Google was a publisher prior to notification of the defamatory material, since it cannot be said that Google either knew or ought to have known of the defamatory comments. ${ }^{38}$

Davison v Habeeb \& Ors (Davison) ${ }^{39}$ also concerned Google's Blogger.com service, and held that Google was not just a passive facilitator, but rather the provider of a giant noticeboard; ${ }^{40}$ it has control, and can take notices down. ${ }^{41}$ But the Court said that due to the volume of use, Google should not be considered liable for continued publication until after notification and failure to remove the defamatory material. ${ }^{42}$

32 Godfrey, above n 30, at 208-209.

${ }^{33}$ At 209.

${ }^{34}$ At 207.

35 Tamiz v Google Inc [2013] 1 WLR 2151 (CA) [Tamiz].

${ }^{36}$ At [34].

${ }^{37}$ At [34].

${ }^{38}$ At [26].

${ }^{39}$ Davison v Habeeb \& Ors [2011] EWHC 3013 (QB) [Davison].

${ }^{40}$ At [41].

${ }^{41}$ At [38].

${ }^{42}$ At [47]. 
Sadiq v Baycorp (NZ) Ltd (Sadiq) ${ }^{43}$ was the first case in New Zealand to consider the liability of an internet intermediary for third party defamation. The defendant had the ability to remove defamatory material posted on its website, but failed to take any measures to do so after requested to by the plaintiff. ${ }^{44}$ The Court essentially applied the Byrne approach, holding that there was an arguable case that the defendant was a publisher of the material. ${ }^{45}$

Associate Judge Doogue considered knowledge to be necessary, saying that " $[\mathrm{t}]$ here would need to be evidence that some human agent of the defendant adverted to the presence of the statement on the website and nonetheless took no steps for its removal". 46

Wishart v Murray (Wishart) ${ }^{47}$ considered whether the creator of a Facebook page could be held liable for defamatory content posted on the page by other users. The defendant had the ability to control content by deleting posts and blocking individual users from the page. ${ }^{48}$

Courtney $\mathrm{J}$ drew an analogy with the noticeboard in Byrne: the host of a Facebook page is essentially creating a noticeboard, on which anyone can post comments. ${ }^{49}$ She said that "[t]hose who host Facebook pages or similar are not passive instruments or mere conduits of content posted on their Facebook page. ${ }^{50}$ They will be regarded as publishers of defamatory material made by anonymous users in two circumstances. The first is if they know of the defamatory statement and fail to remove it within a reasonable time in circumstances that give rise to an inference that they are taking responsibility for it. A request by the person affected is not necessary. The second is where they do not know of the defamatory posting but ought, in the circumstances, to know that postings are being made that are likely to be defamatory". 51

\footnotetext{
${ }^{43}$ Sadiq v Baycorp (NZ) Ltd HC Auckland CIV 2007-404-6421, 31 March 2008 [Sadiq].

${ }^{44}$ At [58].

45 Sadiq, above n 43, at [58].

${ }^{46}$ At [54].

${ }^{47}$ Wishart v Murray [2013] NZHC 540 [Wishart].

${ }^{48}$ At [116].

${ }^{49}$ At [116].

${ }^{50}$ At [117].

${ }^{51}$ At [117].
} 
The second circumstance is notable, because it departs from the Byrne approach, adopted in Sadiq, that actual knowledge is necessary. If the defendant was not aware of the defamatory material, it will still be liable if it ought, in the circumstances, to know that postings are being made that are likely to be defamatory. It is not clear what kind of threshold would be required before it can be found that a defendant ought, in the circumstances, to know that postings are being made that are likely to be defamatory, but it leans closer to the strict liability origins of the tort than Sadiq does.

The Court held that the plaintiff had a tenable case that the defendant was a publisher. $^{52}$

Karam v Parker $(\text { Karam })^{53}$ was also decided by Courtney J. The defendant hosted a Facebook page and a website; in respect of both, defamatory content had been posted by others.

Courtney $\mathrm{J}$ affirmed her points in Wishart, including the two circumstances in which Facebook page hosts will be publishers of posts made by third parties. ${ }^{54}$ She held that the defendant, as administrator of the Facebook page, was a publisher of the statements. ${ }^{55}$

Her Honour also held the defendant to be a publisher of comments by third parties posted on his website. ${ }^{56}$ The defendant had control over content, and actively moderated it. ${ }^{57}$

Thus online content hosts will normally be liable when they have been notified of defamatory material, and have the ability to remove it but fail to do so. Wishart and Karam suggest that a defendant can be liable even without knowledge, provided it ought, in the circumstances, to know that postings are being made that are likely to be defamatory. This departs from the English law.

\footnotetext{
52 Wishart, above n 47, at [122].

${ }^{53}$ Karam v Parker [2014] NZHC 737 [Karam].

${ }^{54}$ At [13].

55 At [19].

${ }^{56}$ At [23].

57 At [23].
} 
A search engine is an automated retrieval system that operates on keywords. It has pre-programmed algorithms, and produces a list of results; results are hyperlinks (links to other web pages), and contain "snippets" of the web pages linked to. ${ }^{58}$

\section{(a) England and Wales}

The English case Metropolitan International School Ltd v Designtechnica Corp (Metropolitan $)^{59}$ held that Google Inc, as operator of its search engine, was not a publisher of snippets in search results. ${ }^{60}$ Eady $\mathrm{J}$ applied an approach he had earlier developed in the case of Bunt $v$ Tilley (Bunt) ${ }^{61}$ intermediaries that only play a role of passive facilitator are not publishers for the purposes of defamation law. ${ }^{62}$ On the facts of Metropolitan, Eady J held that Google Inc had not authorised or caused the snippet to appear on the user's screen in any meaningful sense; ${ }^{63}$ it had only played the role of facilitator, ${ }^{64}$ and there had been no human input. ${ }^{65}$

Eady J considered it was not possible to draw a complete analogy with a website host, because the search engine operator cannot press a button to ensure the offending words will never reappear on a snippet; ${ }^{66}$ any blocking process could be evaded by the author simply moving the material elsewhere.

Even after notification, Google still was not a publisher due to its lack of control. ${ }^{67}$

In Bunt, Eady $\mathrm{J}$ had said there must be knowing involvement in the process of the publication of the relevant words. ${ }^{68}$ With only a passive role, the defendant was a mere conduit, and not liable. ${ }^{69}$

\footnotetext{
${ }^{58}$ A v Google New Zealand Ltd HC Auckland CIV-2011-404-2780, 12 September 2012 [A v Google] at [7]-[10].

${ }^{59}$ Metropolitan International School Ltd v Designtechnica Corp [Metropolitan].

${ }^{60}$ At [124].

${ }^{61}$ Bunt v Tilley [2006] EWHC 407 (QB) [Bunt].

${ }^{62}$ Metropolitan, above n 59, at [36]; Bunt, above n 61, at [36]-[37].

63 Metropolitan, above n 59, at [51].

${ }^{64}$ At [51].

${ }^{65}$ At [50].

${ }^{66}$ At [55].

${ }^{67}$ At [124].
} 
In New Zealand, Google New Zealand Ltd was the defendant in the case $A v$ Google. The case was ultimately decided on the basis of Google New Zealand Ltd's status as a subsidiary, because it did not own or have legal control over the Google search engine - rather its parent Google Inc did. ${ }^{70}$ However, the Court provided some obiter dicta and considered that a search engine could be a publisher.

Associate Judge Abbot considered that holding a search engine operator to be a publisher of snippets is consistent with the broad common law definition of "publication" as being the communication of a statement to just one other person. ${ }^{71}$ To hold that this does not apply when the repetition occurred without human input could unnecessarily confuse the law. ${ }^{72}$ His Honour said that it may be better to hold a search engine a publisher, but with access to the defence of innocent dissemination where the defendant has not received notification. ${ }^{73}$ Thus search engines could be liable when the hyperlink is removed but snippets continue to appear. ${ }^{74}$

It was held that the plaintiff had a tenable case that Google was a publisher. ${ }^{75}$ But the case was struck out because the defendant was only a subsidiary, ${ }^{76}$ so the law as to whether search engines can be held liable as a publisher was not ascertained definitively.

\section{(c) Australia}

Two recent Australian decisions are inconsistent.

In the case Trkulja $v$ Google, ${ }^{77}$ Google search results brought up links to web pages and images of the plaintiff with several people associated with the Melbourne criminal underworld.

${ }^{68}$ Bunt, above n 61, at [36]-[37].

${ }^{69}$ At [36].

${ }^{70}$ A v Google, above n 58, at [46].

${ }^{71}$ At [73].

${ }^{72}$ At [73].

${ }^{73}$ At [73].

${ }^{74}$ At [73].

${ }^{75}$ At [75].

${ }^{76}$ At [76].

77 Trkulja v Google (No 5) [2012] VSC 533 [Trkulja]. 
Beach J held that it was open to the jury to conclude that Google intended to publish, even before notification, everything produced by its automated systems, which its employees created and allowed to operate, because Google is similar to a newsagent. ${ }^{78}$ His Honour, without stating that Metropolitan was decided wrongly on its facts, disagreed with any general rule that passive intermediaries cannot be held liable as publishers, because such a rule would cut across the library and newsagent line of cases. ${ }^{79}$ Therefore Google can be liable as a publisher, even without notice of the content of the material. ${ }^{80}$

Bleyer $v$ Google Inc ${ }^{81}$ was decided differently. McCallum $\mathrm{J}$ accepted evidence that there is no human input in the application of Google's search engine besides the creation of the algorithm. In these circumstances, the judge said, performance of the function of the algorithm is not capable of establishing liability as a publisher at common law. ${ }^{82}$ She disagreed with the decision in Trkulja, and held that Google cannot be liable as a publisher of the results produced by its search engine, at least prior to notification. ${ }^{83}$

So on the basis of Metropolitan, search engines are not publishers in England and Wales. But the case of $A v$ Google opens the door for the law in New Zealand to go a different way, and treat search engines as publishers. This would be consistent with Trkulja in Australia, but inconsistent with Bleyer. One problem with the Metropolitan and Bleyer approach is that it renders the innocent dissemination defence redundant to search engine operators. The defence is intended for what are sometimes termed termed 'secondary' publishers, and operates on the premise that such passive defendants are publishers. I now turn to that defence.

C Whether the defence of innocent dissemination is available to internet intermediaries in respect of content posted by third parties

New Zealand's defence of innocent dissemination is codified in s 21 of the Defamation Act 1992, which provides that:

\footnotetext{
${ }^{78}$ Trkulja, above $\mathrm{n} 77$, at [18].

${ }^{79}$ At [28].

${ }^{80}$ At [30].

${ }^{81}$ Bleyer $v$ Google Inc [2014] NSWSC 897.

${ }^{82}$ At [83].

${ }^{83}$ At [83].
} 
In any proceedings for defamation against any person who has published the matter that is the subject of the proceedings solely in the capacity of, or as the employee or agent of, a processor or a distributor, it is a defence if that person alleges and proves-

(a) that that person did not know that the matter contained the material that is alleged to be defamatory; and

(b) that that person did not know that the matter was of a character likely to contain material of a defamatory nature; and

(c) that that person's lack of knowledge was not due to any negligence on that person's part.

"Processor" is defined in s 2(1) as a person who prints or reproduces, or plays a role in printing or reproducing, any matter; "distributor" includes booksellers and librarians. ${ }^{84}$

Section 21 has not been discussed in depth in respect of internet intermediaries, but was briefly considered in Karam. In relation to posts made by users of the defendant's website, which the defendant moderated, Courtney J considered that the defendant did not fall within the scope of $\mathrm{s} 21 .^{85}$ The judge presumably thought the same for posts made by third parties on the defendant's Facebook page, without saying so expressly. Regarding the Facebook page, presumably it is because of Courtney J's finding that the defendant knew that the posts on the page did, or were likely to, contain defamatory material. She did not provide separate reasons for her conclusion that $\mathrm{s} 21$ does not apply, and tied her analysis of the issue with the issue of whether the defendant was a publisher. ${ }^{86}$

Internet intermediaries could arguably establish the defence prior to receiving notification of the defamatory material, but once notified it is clear that paras (a)-(c) cannot be satisfied. Thus the Sadiq approach to publication effectively subsumes the defence. Karam and Wishart move closer to strict liability, but still subsume the defence: whenever the defendant ought, in the circumstances, to know that postings are being made that are likely to be defamatory, para (c) of s 21 will not be satisfied. The onus is on the plaintiff to show that the defendant ought, in the circumstances, to know, rather than on the defendant to establish the elements of s 21.

${ }^{84}$ Defamation Act 1992, s 2(1).

${ }^{85} \mathrm{Karam}$, above $\mathrm{n} 53$, at [23].

${ }^{86}$ At [7]-[23]. 
The Australian case Trkulja held that, having been notified of the material, Google could not satisfy the requirements of the innocent dissemination defence. ${ }^{87}$ Similarly, in Godfrey in England it was held that the defendant could not establish the defence once it knew of the defamatory material and chose not to remove it. ${ }^{88}$

\section{Conclusion on the current law}

Thus the common law in New Zealand may be moving away from the United Kingdom's. In particular, the Karam and Wishart decisions have said that the defendant's actual knowledge of the defamatory material is unnecessary, and $A v$ Google has set the path for search engines to be liable. Defendants may be able to avail themselves of the defence of innocent dissemination prior to notification of the defamatory material, but not after.

\section{Comparison with Safe Harbour Overseas}

A United Kingdom

1 Defamation Act 2013, s 5

Section 5 of the Defamation Act 2013 provides website operators with a safe harbour. It is a defence for the operator to show that it was not the operator who posted the statement on the operator's website. ${ }^{89}$

The Act does not specify whether an "operator" is someone who has control over the site itself or rather the specific content, but the latter is more likely, ${ }^{90}$ in line with the New Zealand Bill.

The defence is defeated if the claimant shows that: it was not possible for the claimant to identify the person who posted the statement,,${ }^{91}$ the claimant gave the operator a

${ }^{87}$ Trkulja, above n 77, at [41].

${ }^{88}$ Godfrey, above n 30, at 206.

${ }^{89}$ Defamation Act 2013 (UK), s 5(2).

${ }^{90}$ Richard Parkes and others Gatley on Libel and Slander (12th ed, Sweet \& Maxwell, London, 2013) [Gatley], at [6.39].

91 Defamation Act 2013 (UK), s 5(3)(a). 
notice of complaint in relation to the statement, ${ }^{92}$ and the operator failed to respond to the notice of complaint in accordance with any provision contained in regulations. ${ }^{93}$

Further details are contained separately in the Defamation (Operators of Websites) Regulations 2013, which prescribe the procedure operators must follow. If the operator has no means of contacting the poster, then it must, within 48 hours of receiving a notice of complaint, remove the statement. ${ }^{94}$ Otherwise, the operator must contact the poster within 48 hours of receiving notice..$^{95}$ If the poster fails to respond, then the operator must remove the statement. ${ }^{96}$ If the poster responds but does not include all required information, or the information is obviously false, then the operator must remove the statement. ${ }^{97}$ If the poster responds and consents to removal, then the operator must remove the material. ${ }^{98}$ If the poster responds and does not consent to the removal of the material, then the operator must leave the content up and inform the complainant of that. ${ }^{99}$ If the poster consents, the operator must also provide the poster's name or address to the complainant. ${ }^{100}$

There is a different procedure when posters persistently re-post the same or similar material: if a notice of complaint has been received on two or more previous occasions, and on each occasion the material was removed, then on receipt of a further complaint the operator must remove the statement within 48 hours. ${ }^{101}$ There is no counter-notice process in this situation.

The defence will be defeated if the claimant establishes malice on the part of the website operator. ${ }^{102}$ Malice should be given its common law meaning, ${ }^{103}$ specifically that the defendant did not believe the material published was true ${ }^{104}$ or recklessly failed to consider its truth or falsity. ${ }^{105}$ Thus a website operator would be liable if he

\footnotetext{
92 Defamation Act 2013 (UK), s 5(3)(b).

${ }^{93}$ Section 5(3)(c).

${ }^{94}$ Defamation (Operators of Websites) Regulations 2013 (UK), sched, para 3(1).

${ }_{95}$ Paragraph 2(1).

96 Paragraph 5(1).

97 Paragraph 6.

98 Paragraph 7(2).

${ }^{99}$ Paragraph $8(2)(a)$.

100 Paragraph 8(2)(b).

101 Paragraph 9(2).

102 Defamation Act 2013 (UK), s 5(11).

103 Gatley, above n 90, at [6.40].

${ }^{104}$ Horrocks v Lowe [1075] AC 135 (HL) [Horrocks] at 149-150.

105 At 150.
} 
knew the statement was false or was reckless as to whether it was true or false; ${ }^{106}$ however, it is not clear whether failing to remove the content once notified of its falsity will amount to malice. ${ }^{107}$ If so, the defence will be defeated once the website operator is made aware of the defamatory material, even if the author is identifiable. Gatley suggests that this is supported by s 5's reference to malice in regard to "the posting of the statement", ${ }^{108}$ which likely means that "posting" continues while the statement remains on the site. ${ }^{109}$ With respect, this would undermine the defence, because an operator will not be a publisher until it has received notification, so the defence would not add anything to the existing law.

The notice of complaint must comply with several requirements. However, it does not need to include anything substantive about the unlawfulness of the post, just the ways in which it is defamatory. Gatley has expressed concern about this, on the basis that a website operator should not be required to reveal the identity of the creator of the content nor take down the statement on the basis of "half the story". ${ }^{110}$ However, the first limb of that criticism is unfounded because the operator can only reveal the identity of the poster if the poster consents. The second limb only applies if the poster cannot be contacted or fails to submit a valid counter-notice.

\section{Defamation Act 2013, s 10}

A further protection is $\mathrm{s} 10$ of the Act, which says that courts do not have jurisdiction to hear and determine an action for defamation brought against a person who was not the author, editor or publisher of the statement complained of unless the court is satisfied that it is not reasonably practicable for an action to be brought against the author, editor or publisher. "Editor" means a person having editorial or equivalent responsibility for the content of the statement or the decision to publish it, ${ }^{111}$ and "publisher" means a commercial publisher who issues material containing the statement in the course of its business issuing material to the public. ${ }^{112}$ This section is not specific to internet intermediaries.

\footnotetext{
106 Gatley, above n 90, at [6.40].

107 At [6.40].

108 Defamation Act 2013 (UK), s 5(11).

109 Gatley, above n 90, at [6.40].

110 At [6.40].

111 Defamation Act 2013 (UK), s 10(2); Defamation Act 1996 (UK), s 1(2).

112 Defamation Act 2013 (UK), s 10(2); Defamation Act 1996 (UK), s 1(2).
} 
The provision does not contain guidance on what constitutes "not reasonably practicable". Gatley suggests that it would be "not reasonably practicable" if a successful claim were of no real value, for instance if the author was insolvent or was based in a jurisdiction in which the judgment could not be enforced. ${ }^{113}$ Another issue is whether the author's refusal to allow his or her contact information to be passed on to the complainant will amount to "not reasonably practicable", or whether the complainant would be expected to apply for a Norwich Pharmacal order. Gatley notes that if failure to utilise Norwich jurisdiction would prevent a claim being brought against a website operator, the s 5 notice procedures would be redundant, which Parliament presumably did not intend. ${ }^{114}$

\section{Defamation Act 2013, s 13}

It is worth mentioning $\mathrm{s} 13$, which provides that, in a successful action for defamation, whether or not a website operator itself is liable, courts may order the operator to remove the statement. ${ }^{115}$

This gives the courts a further avenue for enforcing an injunction against the author, by allowing it to order the website operators hosting the content to remove it.

\section{$4 \quad$ Summary}

Thus the Defamation Act 2013 essentially provides two levels of protection to online intermediaries. The first is contained in s 10, namely that no proceedings can be brought against an intermediary unless the court is satisfied that it is not reasonably practicable for an action to be brought against the author, editor or publisher of the content. If the court is so satisfied, then the second layer of protection, s 5, comes in.

\section{B $\quad$ United States}

$1 \quad$ Communications Decency Act 1996, s 230

Section 230 of the Communications Decency Act $1996^{116}$ (CDA) provides internet intermediaries with immunity for content they did not create.

113 Gatley, above $n$ 90, at [6.45].

${ }^{114}$ At [6.45]

115 Defamation Act 2013 (UK), s 13(1). 
Prior to the CDA, the law relating to the liability of internet intermediaries for defamatory material created by third parties was problematic. Some cases held internet intermediaries to be publishers, which were liable for defamation, while others held them to be distributors, which were not liable. Importantly, the basis of the distinction was the exercise of editorial control, ${ }^{117}$ which significantly disincentivised such control. Section 230 was intended to encourage editorial control, and prevent fear of liability as publishers. ${ }^{118}$

Section 230 of the CDA provides:

(c) Protection for "Good Samaritan" blocking and screening of offensive material

(1) Treatment of publisher or speaker

No provider or user of an interactive computer service shall be treated as the publisher or speaker of any information provided by another information content provider.

\section{(2) Civil liability}

No provider or user of an interactive computer service shall be held liable on account of-

(A) any action voluntarily taken in good faith to restrict access to or availability of material that the provider or user considers to be obscene, lewd, lascivious, filthy, excessively violent, harassing, or otherwise objectionable, whether or not such material is constitutionally protected; or

(B) any action taken to enable or make available to information content providers or others the technical means to restrict access to material described in paragraph (1).

"Interactive computer service" is defined as "any information service, system, or access software provider that provides or enables computer access by multiple users to a computer server, including specifically a service or system that provides access to the Internet and such systems operated or services offered by libraries or educational

116 Communications Decency Act 47 USC $§ 230$ [CDA].

117 Stratton Oakmont, Inc v Prodigy Services Co 1995 WL 323710 (NY Sup Ct 1995) at 4.

118 Zeran v America Online, Inc 129 F 3d 327 (4th Cir 1997) [Zeran] at 331. 
institutions"; 119 and "information content provider" is defined as "any person or entity that is responsible, in whole or in part, for the creation or development of information provided through the Internet or any other interactive computer service". ${ }^{120}$

The stated policy of the Act includes the removal of disincentives for the development and utilisation of blocking and filtering technologies that empower parents to restrict their children's access to objectionable or inappropriate online material. ${ }^{121}$ Section 230 applies more broadly than the statutory defences of innocent dissemination in New Zealand and the United Kingdom; ${ }^{122}$ it also applies more broadly than the safe harbours contained in s 5 of the Defamation Act 2013 (UK) and cl 20 of the Harmful Digital Communications Bill. It applies to all providers and users of interactive computer services. It even operates where the provider or user is aware of the nature of the content it is hosting or carrying. ${ }^{123}$

Paragraph (2) prevents intermediaries from being sued by content creators for removing that content. Notably, there is no notice-takedown requirement.

The first case to authoritatively consider s 230 was Zeran v America Online, Inc (Zeran). ${ }^{124}$ America Online (AOL) operated a bulletin board, on which a third party posted defamatory material. After being notified by the plaintiff, AOL removed the material, but it continued to reappear.

The plaintiff argued that s 230 affects only publisher liability, and that AOL was liable as a distributor of the material. The District Court considered that such liability was pre-empted by s 230, and the Court of Appeals upheld that decision. Chief Judge Wilkinson said that s 230 "creates a federal immunity to any cause of action that would make service providers liable for information originating with a third-party user of the service. Specifically, s 230 precludes courts from entertaining claims that would place a computer service provider in a publisher's role". ${ }^{125}$

$119 \mathrm{CDA}$, above n 116, s 230(f)(2).

120 Section 230(f)(3).

121 Section 230(b).

122 Collins, above n 26, at [31.36].

${ }^{123}$ Batzel v Smith 333 F 3d 1018 (9th Cir 2003) at 1031.

${ }_{124}$ Zeran, above $\mathrm{n} 118$.

125 At 330. 
The CDA applies broadly. ${ }^{126}$ In total, the defence succeeded in 64.4 per cent of defamation decisions. ${ }^{127}$ The main reason for the defence failing was that the defendant was found to be either the source of or otherwise responsible for the content at issue. ${ }^{128}$

Section 230 has not entirely frustrated plaintiffs' relief: many plaintiffs have been able to sue the original authors of the content at issue, and, more importantly, in about half of cases the plaintiffs have succeeded in having the content removed. ${ }^{129}$ Given that the main motivation for plaintiffs in defamation claims is the correction of falsehood and its reputational consequences, ${ }^{130}$ it is significant that so many plaintiffs have obtained that removal.

\section{Improvements to the Harmful Digital Communications Bill}

\section{A Why a safe harbour is needed}

There are good reasons for intermediaries not to be liable for third party defamation. An important issue in this area of the law is freedom of expression. Different countries have struck the balance between right to reputation and freedom of expression differently: some are more pro-plaintiff, while others are more prodefendant. ${ }^{131}$ In enacting s 230 of the CDA, Congress considered freedom of speech implications and chose to immunise interactive computer service providers to avoid the probability of such providers restricting the number and type of messages posted. ${ }^{132}$

\footnotetext{
126 Batzel v Smith, above n 123 at 1030.

127 David Ardia "Free Speech Savior or Shield for Scoundrels: An Empirical Study of Intermediary Immunity under Section 230 of the Communications Decency Act" (2010) 43 Loy LA L Rev 373 at 503.

128 At 442 .

129 At 493.

130 Randall P Bezanson "Libel Law and the Realities of Litigation: Setting the Record Straight" (1985) 71 Iowa Law Review 226 at 228.

131 Russell Weaver "Defamation Law in Turmoil: The Challenges Presented by the Internet" (2000) JILT <www2.warwick.ac.uk/fac/soc/law/elj/jilt/2000_3/weaver/> at [1].

132 Zeran, above n 118, at 331.
} 
New Zealand has no entrenched right to freedom of expression, but does have the Bill of Rights Act 1990, s 14 of which provides that "Everyone has the right to freedom of expression, including the freedom to seek, receive, and impart information and opinions of any kind in any form".

Potential problems of search engine liability have been raised in response to Google v Spain, ${ }^{133}$ which held that a European Union directive allows European Union residents to exercise their "right to be forgotten" online by requesting the removal of search engine results that are "inadequate, irrelevant or no longer relevant." 134 To prevent misuse of the right, search engines must screen requests to determine whether they are legitimate. This is difficult due to the inherent subjectivity of what is "no longer relevant", and the volume of requests that will likely be made. ${ }^{135}$

Such problems could arise by making internet intermediaries liable for third party defamation. Moreover, because it is expensive and difficult for hosts, upon receiving a complaint, to decide whether the material is defamatory and should be taken down, or worth the risk of leaving it up, intermediaries are incentivised to simply remove content. This interferes with the author's freedom of speech.

A safe harbour can be a good solution. The approach in Bunt and Metropolitan, that Google is not a publisher because of its passiveness, may reach a good result with regard to search engine liability, but is inconsistent with the strict liability nature of the tort. The obiter statements in Av Google, and the Australian decision Trkulja are arguably sounder in principle. Similarly with regard to content hosts, the New Zealand cases Karam and Wishart go somewhat closer to the origins of the tort, but could also result in defendants being liable in unjust circumstances. For example, if a website or Facebook page receives so many comments that editorial control is not reasonably possible, then the operator may have no means of avoiding liability except by the innocent dissemination defence, prior to notification.

So a legislative safe harbour is preferable to the disruption of existing principles of defamation law.

\footnotetext{
133 C-131/12 Google Spain v AEPD and Marion Costeja Gonzalez [2014] OJ C 212.

134 Google Spain v AEPD and Marion Costeja Gonzalez, above n 132, at [94].

135 Emily Hong "Transparency and the EU's New 'Right to Be Forgotten”'

$<$ www.chillingeffects.org/weather.cgi?WeatherID=828>.
} 
As currently drafted, search engine operators may not be covered by the safe harbour, unless courts read the provisions broadly. Clause 20(1) states that "This section and section 20A apply to the liability of an online content host for the content of a digital communication posted by a person and hosted by the online content host" [emphasis added]. Clause 4's definition of an online content host contains the words "...on which the communication is posted and accessible by the user" [emphasis added]. On the basis of Metropolitan, search engine operators do not host or store content, ${ }^{136}$ but only generate automatic search results. ${ }^{137}$ In addition, content is not posted on search engines. A distinction is drawn between content hosts and passive intermediaries like search engine operators.

The approach in Metropolitan is based on factual inaccuracies, because it has subsequently been established that search engines do have control over search results, ${ }^{138}$ and thus the distinction is artificial. However, in any event it should be clarified whether search engines are covered by cl 20 .

The importance of protecting search engine operators from liability cannot be overstated. Search engines allow users to find and make sense of the vast amount of information available on the internet and direct their attention to the minute sub-set of information that may be of interest to them. ${ }^{139}$ Currently more than 60 trillion individual web pages exist on the internet, ${ }^{140}$ so a system for sorting and searching those pages is crucial.

Freedom of expression issues are particularly important in the context of search engine liability for third party defamation - search engines play a crucial role in imparting information. ${ }^{141}$

\footnotetext{
136 Metropolitan, above n 59, at [78].

${ }^{137}$ A v Google, above n 58, at [51].

138 C-131/12 Google Spain v AEPD and Marion Costeja Gonzalez [2014] OJ C 212.

139 Peter Leonard "Safe Harbors in Choppy Waters - Building a Sensible Approach to Liability of Internet Intermediaries in Australia” (2010-2011) 3 J Int'l Media \& Ent L 221 at 227.

$140<$ www.google.com/intl/en/insidesearch/howsearchworks/thestory/>.

141 Molly Woods “Don't be Evil: Mantra or Mask? An Analysis of Google’s Liability for Online Defamation” (LLB (Hons) Dissertation, Victoria University of Wellington, 2012) at 24.
} 
Thus search engine operators should be protected by cl 20, and Parliament should clarify whether they will be.

\section{Notice and takedown regime}

At a minimum, three changes should be made to $\mathrm{cl} 20$. First, the author's personal information should be passed on to the complainant if the complainant requests. Currently the author has to provide his or her information to the host, but has the option of letting the host pass it on to the complainant. This potentially leaves complainants without a timely remedy. It is important that complainants who are defamed online can access a remedy, and receiving an anonymous author's information, which the host will have received, directly from the host would likely be quicker than going through the courts to get that information. Clause 20A(1) provides that the District Court or High Court may order the release of the author's information. Little can be said about this order, since no details are provided in the Act, but it would be slower and less convenient to complainants than having the information released to them automatically. If judges are given discretion, there could also be less certainty that the identity will be released.

An advantage to giving anonymous authors that option is that it encourages free speech and debate, without fear of being 'outed'. However, it is reasonably likely that the author's details can be obtained either by order under $\mathrm{cl} 20 \mathrm{~A}$ or by a Norwich Pharmacal order, ${ }^{142}$ so this is essentially an issue of workability. If a complainant is being defamed online, then the extra time it takes to obtain an order to disclose the author's identity could increase the harm being done.

Secondly, there should be the inclusion of a different procedure for repeat posters, as the United Kingdom now has. The Bill's lack of any similar provision means that, in order to be protected, a content host must follow the full notice and counter-notice procedure, even in respect of content that has previously been the subject of a complaint. This is potentially onerous, and something similar to the United Kingdom's approach would be more workable.

142 From which relevant District Court Rules and High Court Rules derive: A v Internet Company of New Zealand [2009] ERNZ 1 at [9]. 
Thirdly, similar to the UK Regulations, ${ }^{143}$ the Bill should state that a counter-notice is not valid if a reasonable content host would consider the author's details contained in the counter-notice to be obviously fake. In such a situation, the host must remove the material. This would disincentivise the provision of false details, and ensure that content is removed if the host does not have the author's details and thus could not disclose them, whether directly or by court order.

An additional improvement could be the provision for a penalty against submitting negligent or malicious notices, ${ }^{144}$ in respect both the original complaint and the author's counter-notice. It is foreseeable that malicious notices or counter-notices could be made, resulting in material wrongly being removed or left in place. This stems in part from the low requirements for the notices (in the case of the original complaint, it need only explain why the content is defamatory or objectionable and should otherwise be removed). Raising the threshold is one possibility, but would place additional responsibility on content hosts to assess the merits of a notice. Thus penalties against submitters of malicious notices could be a better solution. The Digital Millennium Copyright Act 1998 (United States) provides that any person who knowingly makes misrepresentations in notices of copyright infringement can be liable for damages, including any costs and legal fees incurred by the service provider in removing the material. ${ }^{145}$ Such a provision would deter abuse of the safe harbour.

The UK Act contains a further requirement before the defence is lost: that it is not possible to identify the person who made the statement. ${ }^{146}$ This is host-friendly, because the host is not required to follow the notice procedure if the author is identifiable. The disadvantage to complainants will be minimal, because if the author is identifiable then the complainant can contact the author directly. And if the author refuses to remove the content, then presumably the author would not have consented to removal if notified by the host under the procedure. This is a good middle ground between a defence requiring no action by the host, such as s 230 of the CDA, and one requiring a procedure to be followed in every circumstance.

143 Defamation (Operators of Websites) Regulations 2013 (UK), sched, para 6.

144 Richard Clayton “Judge \& Jury? How 'Notice and Take Down' gives ISPs an unwanted role in applying the Law to the Internet" <www.cl.cam.ac.uk/ rnc1/Judge_and_Jury.pdf> at 12. 145 Digital Millennium Copyright Act 17 USC $§ 512(f)$.

146 Defamation Act 2013 (UK), s 5(3)(a). 
The UK Act also has the additional layer of defence in s 10, that no proceedings can be taken against someone who was not the author, editor or publisher of a statement unless it is not reasonably practicable to bring proceedings against the author, editor or publisher. Adopting such a defence would add further protections for content hosts, but some problems with s 10, raised by Gatley, would need to be ironed out. The first issue is whether an unsuccessful application for disclosure of the author's details would be necessary before it is "not reasonably practicable" to bring proceedings against the author. If my first recommendation above were also followed, this would not be a problem because the author's details would be passed to the complainant on request. Secondly, whether the author being insolvent or based in a jurisdiction where the judgment could not be enforced would amount to "not reasonably practicable". In principle, however, such a protection would be desirable, and shift the focus of defamation actions away from the host and to the author.

The UK Act states that an operator who "moderates" the statement does not lose the defence. ${ }^{147}$ This appears at first to clarify the situation, but actually adds little, because presumably it will not extend to editing. Gatley therefore considers that, despite the provision, operators will likely be cautious and avoid moderation entirely. ${ }^{148}$ Thus, while such a provision could be added to the Bill, it should not be a priority.

\section{Conclusion}

The law relating to liability of internet intermediaries for third party defamation is relatively well settled in the United Kingdom. New Zealand law is less settled, and may depart from English law. The New Zealand approach is more consistent with the strict liability origins of the tort, but may result in liability being imposed on intermediaries when it would not be just to do so. The imposition of liability may also have a chilling effect, as intermediaries are incentivised to remove content once they have received a complaint, without assessing the merits of the complaint.

The safe harbour contained in cl 20 of the Harmful Digital Communications Bill is a solid attempt at providing online content hosts with a further protection against

147 Defamation Act 2013 (UK), s 5(12).

148 Gatley, above n 90, at [6.39]. 
liability for defamatory material created by third parties. But there are clear deficiencies with the clause, and many improvements could be made. This paper has considered the United Kingdom's Defamation Act 2013 and the United States' Communications Decency Act, and has agued for changes to improve the Bill's safe harbour. 


\section{Bibliography}

A Legislation

$1 \quad$ New Zealand

Bill of Rights Act 1990.

Defamation Act 1992.

Harmful Digital Communications Bill 2013 (168-2).

$2 \quad$ United Kingdom

Defamation Act 1996 (UK).

Defamation Act 2013 (UK).

Defamation (Operators of Websites) Regulations 2013 (UK).

\section{$3 \quad$ United States}

Communications Decency Act 47 USC § 230.

Digital Millennium Copyright Act 17 USC $§ 512$.

B Cases

$1 \quad$ New Zealand

A v Google New Zealand Ltd HC Auckland CIV-2011-404-2780, 12 September 2012.

A v Internet Company of New Zealand [2009] ERNZ 1.

Karam v Parker [2014] NZHC 737.

Sadiq v Baycorp (NZ) Ltd HC Auckland CIV 2007-404-6421, 31 March 2008.

Solicitor-General v Siemer HC Auckland CIV 2008-202, 8 July 2008. 
Wishart v Murray [2013] NZHC 540.

$2 \quad$ United Kingdom

Bunt v Tilley [2006] EWHC 407 (QB).

Byrne v Deane [1937] 1 KB 818.

Davison v Habeeb \& Ors [2011] EWHC 3013 (QB).

Day v Bream (1837) 174 ER 212 (Assizes).

Godfrey v Demon Internet Ltd [2001] QB 201, [1999] 4 ER 342 (QB).

Horrocks v Lowe [1975] AC 135 (HL).

Mahfouz v Brisard [2005] EWHC 2304 (QB).

Metropolitan International School Ltd v Designtechnica Corp [2009] EMLR 27 (QB).

Pullman v Walter Hill \& Co Ltd [1891] 1 QB 524 (QB).

Tamiz v Google Inc [2013] 1 WLR 2151 (CA).

$3 \quad$ United States

Batzel v Smith 333 F 3d 1018 (9th Cir 2003).

Cubby, Inc v CompuServe Inc 776 F Supp 135 (SD NY 1991).

Gentry v eBay, Inc 99 Cal App 4th 816 (Ct App 2002).

Lerman v Flynt Distributing Co 745 F 2d 123 (2nd Cir 1984).

Lunney v Prodigy Services Co 683 NYS 2d 557 (AD NY 1998).

Smith v California 361 US 147 (1959).

Stratton Oakmont, Inc v Prodigy Services Co 1995 WL 323710 (NY Sup Ct 1995). 
Zeran v America Online, Inc 129 F 3d 327 (4th Cir 1997).

$4 \quad$ Australia

Bleyerv Google Inc [2014] NSWSC 897.

Trkulja v Google (No 5) [2012] VSC 533.

$5 \quad$ European Union

C-131/12 Google Spain v AEPD and Mario Costeja Gonzalez [2014] OJ C 212.

C Government and Official Materials

(14 November 2013) 694 NZPD 14747.

Harmful Digital Communications Bill (168-2) (select committee report).

Kelby Harmes Harmful Digital Communications Bill - Initial Briefing (Ministry of Justice, 3 March 2014).

Kelby Harmes Harmful Digital Communications Bill - Interim Advice (Ministry of Justice, 25 March 2014).

Ben Keith and Helen Carrad Harmful Digital Communications Bill (PCO 16465/4.17): Consistency with the New Zealand Bill of Rights Act 1990 (Ministry of Justice Advice to the Attorney-General, 2013).

Ministry of Justice Harmful Digital Communications Bill - Departmental Report for the Justice and Electoral Committee (13 April 2014).

D Books

Laws of New Zealand Defamation.

Matthew Collins The Law of Defamation and the Internet (3rd ed, Oxford University Press, New York, 2011). 
Richard Parkes and others Gatley on Libel and Slander (12th ed, Sweet \& Maxwell, London, 2013).

E Journal Articles

David Ardia "Free Speech Savior or Shield for Scoundrels: An Empirical Study of Intermediary Immunity under Section 230 of the Communications Decency Act" (2010) 43 Loy LA L Rev 373.

Randall P Bezanson "Libel Law and the Realities of Litigation: Setting the Record Straight” (1985) 71 Iowa L Rev 226.

Peter Leonard "Safe Harbors in Choppy Waters - Building a Sensible Approach to Liability of Internet Intermediaries in Australia" (2010-2011) 3 J Int'1 Media \& Ent L 221.

Lydia Pallas Loren "Deterring Abuse of the Copyright Takedown Regime by Taking Misrepresentation Claims Seriously" (2011) 46 Wake Forest L Rev 745.

Michael D Scott "Would a 'Right of Reply' Fix Section 230 of the Communications Decency Act?” (2011-2012) 4 J Int'1 Media \& Ent L 57.

\section{F Internet Materials}

Richard Clayton “Judge and Jury? How 'Notice \& Take Down' gives ISPs an unwanted role in applying the Law to the Internet" $<$ www.cl.cam.ac.uk/ rnc1/Judge_and_Jury.pdf $>$.

Emily Hong "Transparency and the EU's New 'Right to Be Forgotten"” $<$ www.chillingeffects.org/weather.cgi? WeatherID $=828>$.

Russell Weaver "Defamation Law in Turmoil: The Challenges Presented by the Internet” (2000) JILT <www2.warwick.ac.uk/fac/soc/law/elj/jilt/2000_3/weaver/>.

\section{G Other Materials}


Auckland District Law Society Inc "Submission to the Justice and Electoral Committee on the Harmful Digital Communications Bill 2013”.

Molly Woods “Don’t be Evil: Mantra or Mask? An Analysis of Google's Liability for Online Defamation" (LLB (Hons) Dissertation, Victoria University of Wellington, 2012).

Google Transparency Report<www.google.com/transparencyreport/>.

<www.google.com/intl/en/insidesearch/howsearchworks/thestory/>.

\section{Word count}

The text of this paper (excluding title page, extract, table of contents, footnotes, and bibliography) comprises approximately 7,987 words. 